\title{
Islam, HAM, dan Diskriminasi: Reinterpretasi Hadis-Hadis Kepemimpinan secara Kontekstual
}

\author{
Muhammad Syachrofi \\ UIN Sulthan Thaha Saifuddin Jambi \\ email: msyachrofi93@gmail.com
}

\begin{abstract}
This paper discusses one of the humanitarian problems that still often occurs today, discrimination. Discrimination is not only contrary to human rights but also contrary to the Islamic view which is rahmah fi al-älamin. But, in fact, Islam is always suspected as a religion that teaches various forms of discriminatory treatment. The accusation is based on Islamic religious texts which narratively teach discrimination. I find that there are two hadiths that are discriminatory about electing leaders. The first hadith is about having to elect a leader from the Quraysh clan. The second hadith is about the prohibition for women to be a leader. Textually, these hadiths are quite problematic because they contain the narration of racial-ethnic discrimination and gender discrimination. Therefore, in this article, I attempt to reinterpret these hadiths by using a contextual approach by analyzing the language and socio-historical context. My conclusion is that these hadiths were stated by the Prophet Muhammad in the temporary cases. Substantially, these hadiths contain the significances that are relevant today.
\end{abstract}

Keywords: Discrimination, Hadith, Human Right, Islam

\begin{abstract}
Abstrak
Tulisan ini mendiskusikan tentang salah satu problem kemanusiaan yang hingga saat ini masih sering terjadi, yaitu diskriminasi. Diskriminasi tidak hanya bertentangan dengan HAM tetapi bertentangan pula dengan ajaran universal Islam yang rahmah fi al-'älamin. Namun faktanya, Islam selalu dicurigai sebagai agama yang mengajarkan berbagai bentuk perlakuan diskriminatif. Tuduhan tersebut didasari atas teks-teks keagamaan Islam itu sendiri yang narasinya terkesan diskriminatif. Penulis menemukan terdapat dua hadis yang bernarasi diskriminatif tentang memilih pemimpin. Pertama, hadis yang mengatakan bahwa pemimpin harus dipilih dari kalangan suku Quraisy. Kedua, hadis yang mencemooh perempuan menjadi seorang pemimpin. Secara tekstual, hadis-hadis ini cukup problematis terutama dalam konteks kekinian, salah satunya, yaitu mengandung unsur diskriminasi rasial-etnis dan diskriminasi jenis kelamin. Oleh karena itu, dalam artikel ini, penulis mencoba membaca ulang hadis-hadis tersebut dengan menggunakan pendekatan kontekstual yaitu dengan menganalisa bahasa serta konteks sosio-historisnya. Hasil temuan dari pembacaan kontekstual penulis adalah bahwa hadis-hadis ini pada dasarnya bersifat temporal dan kasuistik. Namun, pada substansinya terdapat pesan-pesan yang bersifat universal sehingga tetap relevan dalam konteks kekinian.
\end{abstract}

Kata kunci: Diskriminasi, Hadis, HAM, Islam

\section{Pendahuluan}

Di era kemajuan ilmu pengetahuan dan teknologi ini, persoalan hakikat manusia dan kehidupan semakin santer dibahas. ${ }^{1}$ Prinsip-prinsip dasar terkait segala aspek kehidupan manusia seperti

1 Menurut Nurcholish Madjid, penting kiranya memahami konsep manusia menurut al-Qur'an dan Sunnah terlebih dahulu sebelum memahami Islam dan 
politik, ekonomi, sosial dan etika "dituntut" agar selaras dengan prinsip Hak Asasi Manusia (HAM). HAM merupakan suatu tuntutan yang secara moral dapat dipertanggungjawabkan dan juga suatu hal yang sudah selayaknya mendapatkan perlindungan hukum. Tujuan perancangan konsep HAM secara universal sebenarnya memiliki tujuan yang sangat mulia dan humanis. Mengingat seringnya terjadi tindakantindakan yang bertentangan dengan nilainilai kemanusiaan itu sendiri.

HAM mulai menjadi isu internasional sejak berakhirnya Perang Dunia II, yang ditandai dengan terlaksananya Universal Declaration of Human Right (UDHR) atau di Indonesia dikenal dengan DUHAM (Deklarasi Universal Hak Asasi Manusia) oleh PBB pada 10 Desember $1948,{ }^{2}$ yang terdiri dari 30 pasal. ${ }^{3}$ Secara garis besar, hak-hak asasi manusia yang diatur oleh DUHAM antara lain adalah: (1) hak untuk berpikir dan mengutarakan pandangan; (2) hak untuk memiliki sesuatu; (3) hak untuk

HAM secara benar. Nurcholish Madjid, "Konsep Islam tentang Manusia dan Implikasinya terhadap Apresiasi Muslim Mengenai Hak-Hak Sipil dan Politik," dalam Islam dan Humanisme: Aktualisasi Humanisme Isam di Tengah Krisis Humanisme Universal (Yogyakarta: Pustaka Pelajar, 2007), 18.

2 Peter Baehr et al., Instrumen Internasional Pokok Hak Asasi Manusia, ed. \& trans. oleh Adnan Buyung Nasution dan A. Patra M. Zen (Jakarta: Yayasan Obor Indonesia, 2006), 20.

${ }^{3}$ Makhrur Adam Maulana, Konsepsi HAM dalam Islam antara Universalitas dan Partikularitas (Yogyakarta: Pustaka Ilmu, 2015), 23. mendapatkan pendidikan dan pengajaran; (4) hak untuk menganut agama/kepercayaan; (5) hak untuk hidup; (6) hak untuk memperoleh nama baik; dan (7) hak untuk mendapatkan pekerjaan. Seiring waktu, DUHAM yang semulanya hanya berupa kesepakatan moral-nonyuridis kini telah menjadi norma yang mengikat secara yuridis yang disepakati oleh sejumlah negara yang ikut serta dalam konvensi HAM internasional. ${ }^{4}$

Sementara gagasan HAM dalam Islam baru pertama kali dideklarasikan pada tahun 1981 yakni Universal Islamic Declaration of Human Right (UIDHR). ${ }^{5}$ Kemudian disusul deklarasi pada 5 Agustus 1990 oleh The Organization of Islamic Conference (OIC) atau Organisasi Konferensi Islam (OKI). Deklarasi ini dikenal dengan Cairo Declaration of Human Right in Islam (CDHRI) yang berisi 25 pasal tentang hak asasi manusia. ${ }^{6}$ Deklarasi ini terlaksana atas reaksi sebagian-untuk tidak mengatakan keseluruhan-negara Islam yang tidak menyetujui konsep HAM internasional yang menurut mereka dilandasi semangat sekuler dan bertentangan dengan syariah

${ }^{4}$ Maufur, Norhaidi Hasan, dan Syaifudin Zuhri, Modul Pelatihan Figh dan HAM (Yogyakarta: LKiS, 2014), 7. ${ }^{5}$ Maufur, Hasan, dan Zuhri, 9.

6 Maulana, Konsepsi HAM dalam Islam antara Universalitas dan Partikularitas, 23. 
Islam. ${ }^{7}$ Namun tidak semua pasal dalam HAM internasional bertentangan dengan syariat Islam melainkan hanya beberapa isu "sensitif" saja.

Kendati demikian, bukan berarti sebelum tahun 1990 Islam tidak mengenal atau mengajarkan nilai-nilai hak asasi manusia. Makhrur Adam Maulana mengutip dalam buku Tarikh Islam karya Haji Oemar Said Tjokroaminoto, bahwa untuk pertama kalinya Nabi Muhammad SAW. berpidato tentang masalah hak asasi adalah pada saat melakukan haji wada' dan di hadapan kurang lebih 124.000 jamaah haji. ${ }^{8}$ Selain itu, substansi konsep HAM yang dapat ditemukan dalam ajaran Islam bisa dilihat antara lain pada QS. AlMa'idah (5) ayat 32.

Tidak keliru jika Masykuri Abdillah mengatakan bahwa mayoritas intelektual muslim Indonesia menerima formulasi HAM universal dan memandangnya sejalan dengan nilai-nilai universal Islam. $^{9}$ Salah satu tokoh intelektual muslim Indonesia, misalnya Nurcholish Madjid, mengatakan bahwa beberapa bagian penting ajaran Islam sangat relevan dengan konsep HAM yaitu seperti konsep egalitarianisme, kesiapan

7 Maufur, Hasan, dan Zuhri, Modul Pelatihan Figh dan HAM, 9.

8 Maulana, Konsepsi HAM dalam Islam antara Universalitas dan Partikularitas, 13.

9 Masykuri Abdillah, Demokrasi di Persimpangan Makna (Yogyakarta: Tiara Wacana, 1999), 110. menerima keberadaan agama lain dan komunitas lain, kebutaan terhadap ras dan tradisi kesadaran legal yang secara mendalam terbakukan dalam syariah. ${ }^{10}$ Argumen keagamaan yang sesuai dengan pernyataan Nurcholish Madjid di atas adalah QS. Al-Hujurat (49) ayat 13.

Ayat di atas menjelaskan bahwa Islam telah mengajarkan nilai-nilai universal yang memandang manusia dalam derajat yang sama tanpa memperdulikan asal-usul, ras, warna kulit, jenis kelamin, dan agama. Menurut M. Quraish Shihab, nilai-nilai universal Islam atau universalisme Islam seharusnya dipahami sebagai keberlakuan ajaran Islam untuk semua orang dan untuk seluruh dunia. ${ }^{11}$ Nilai-nilai universalisme Islam sebenarnya mengacu pada konsep maqāṣid al-syarīah, yang dalam bahasa Abdurrahman Wahid disebut dengan konsep "lima jaminan dasar". Menurut Abdurrahman Wahid, lima jaminan dasar inilah yang menampilkan ajaran universalisme Islam secara sempurna, yaitu: (1) keselamatan fisik warga masyarakat dari tindakan badani di luar ketentuan hukum; (2) keselamatan keyakinan agama masing-

\footnotetext{
${ }^{10}$ Madjid, “Konsep Islam tentang Manusia dan Implikasinya terhadap Apresiasi Muslim Mengenai HakHak Sipil dan Politik," 18-19.

11 Muhammad Quraish Shihab, Membumikan alQur'an: Fungsi dan Peran Wahyu dalam Kehidupan Masyarakat (Bandung: Mizan, 2013), 330.
} 
masing, tanpa ada paksaan untuk berpindah agama; (3) keselamatan keluarga dan keturunan; (4) keselamatan harta benda dan milik pribadi di luar prosedur hukum; dan (5) keselamatan profesi. ${ }^{12}$

Namun, ada sedikit perbedaan penafsiran atas konsep lima jaminan dasar oleh Abdurrahman Wahid ini dengan konsep maqāṣid al-syarī'ah pada umumnya, yaitu pada aspek hifz al-dìn. Ulama klasik pada umumnya memaknai hifz al-dìn sebagai komitmen memelihara agama yang-bisa dikatakan-bersifat defensifapologetik. ${ }^{13}$ Berbeda dengan itu, Abdurrahman Wahid menafsirkan hifz aldin-atau dalam bahasanya disebut dengan jaminan dasar akan keselamatan keyakinan agama masing-masing-sebagai komitmen untuk melandasi hubungan antar-warga masyarakat atas dasar sikap saling hormat, yang akan mendorong tumbuhnya kerangka sikap tenggang rasa dan saling pengertian yang besar. Karena pada dasarnya, sikap toleransi adalah bagian inheren dari kehidupan manusia. ${ }^{14}$

\footnotetext{
12 Abdurrahman Wahid, "Universalisme Islam dan Kosmopolitanisme Peradaban Islam," dalam Islam Universal (Yogyakarta: Pustaka Pelajar, 2007), 2-3.

13 Hifz al-din oleh ulama klasik dimaknai sebagai upaya menegakkan dan meneguhkan agama di dalam hati dengan mengikuti hukum-hukumnya serta menjaga kelanggengan agama Islam dari perlawanan musuh dengan cara berjihad dan sebagainya. Lihat Abdul Wahhab Khallaf, Ilmu Ushul Fiqih, terj. oleh Moh Zuhri dan Ahmad Qarib (Semarang: Dina Utama, 2014), 372.$$
14 \text { Wahid, "Universalisme Islam dan }
$$
Kosmopolitanisme Peradaban Islam," 3.
}

Apa yang dinyatakan oleh Abdurrahman Wahid di atas selaras dengan upaya reformasi maqașid alsyarī'ah yang dilakukan oleh Jasser Auda. Ia mengusulkan beberapa usulan di antaranya mereformasi maqașid al-syari'ah dalam perspektif kontemporer, yaitu dari maqașid al-syarī’ah yang dulunya bernuansa protection (penjagaan) dan preservation (pelestarian) menuju maqașid al-syarīah yang bernuansa development (pengembangan) dan pemuliaan human rights (hak-hak asasi). ${ }^{15}$

Namun demikian, sangat disayangkan hingga dewasa ini Islam masih sering dicurigai sebagai agama yang diskriminatif; tidak menjunjung nilai-nilai universal terutama mengenai hak-hak asasi manusia. Tuduhan tersebut tidak bisa dipungkiri juga karena beberapa fakta mengungkapkan bahwa sejumlah kaum muslimin masih melakukan pembedaan sikap dan perlakuan terhadap sesama manusia hanya karena terdapat perbedaan pada aspek tertentu. Sikap tersebut didasari dari pemahaman mereka terhadap teksteks agama yang secara tekstual mengandung unsur diskriminatif. Penulis menemukan terdapat dua hadis yang

15 Lihat kata pengantar oleh Amin Abdullah dalam Jasser Auda, Membumikan Hukum Islam Melalui Maqasid Syariah, terj. oleh Rosidin dan 'Ali 'Abd el-Mun'im (Bandung: Mizan Pustaka, 2015), 11. 
bernarasi diskriminatif terkait persoalan memilih pemimpin. Pertama, hadis yang menyatakan bahwa pemimpin itu harus dari kalangan suku Quraisy. Kedua, hadis yang terang-terangan mencemooh kepemimpinan seorang perempuan.

Dalam memahami hadis-hadis tersebut, penulis menggunakan metode pemahaman hadis kontekstual. Yang dimaksud dengan pendekatan kontekstual adalah memahami hadis tidak hanya dengan menganalisa bahasa melainkan juga harus dengan memerhatikan konteks sosio-historis yang mengitarinya. Secara metodologis, pendekatan ini dilakukan pertama-tama dengan cara menganalisa makna kebahasaan. Kemudian, dilanjutkan dengan menganalisa konteks historis munculnya hadis baik makro maupun mikro. Konteks historis makro adalah konteks yang meliputi situasi dan kondisi di lokasi dan waktu teks tersebut lahir. Sedangkan konteks historis mikro adalah peristiwa-peristiwa tertentu yang melatarbelakangi munculnya teks, ${ }^{16}$ yang dalam keilmuan hadis disebut dengan asbāb al-wurūd. Langkah terakhir yaitu menganalisa hubungan yang dapat menjembatani konteks munculnya teks dengan konteks kekinian agar dapat

16 Lihat Sahiron Syamsuddin, Hermeneutika dan Pengembangan Ulumul Qur'an (Yogyakarta: Pesantren Nawesea, 2017), 142. ditemukan substansi dan signifikansi dari hadis-hadis tersebut.

\section{Teori Diskriminasi}

Diskriminasi merupakan salah satu problem hak asasi manusia yang hingga kini belum dapat diselesaikan. Sekiranya diskriminasi memang tidak dapat dihapuskan secara total melainkan hanya bisa diminimalisir. Karena berkaitan dengan karakter dasar manusia yang memiliki kecenderungan untuk selalu membeda-bedakan antara satu hal dengan hal lainnya. Terma diskriminasi dalam bahasa Inggris disebut dengan "discrimination" yang berasal dari bahasa Yunani "discernere" yang artinya adalah melihat, mengenali atau membedakan. Dalam pengertian bahasa Inggris "discrimination" memiliki dua pengertian atau makna. Pertama bermakna "to distinguish" atau "to differentiate between people, things, etc" yaitu membedakan antara dua hal, orang, atau lain-lain. Makna kedua yaitu "to make an adverse distinction" (membuat perbedaan yang merugikan) atau "to distinguish unfavourably from others" (membedakan antara satu dengan lainnya secara tidak menguntungkan). ${ }^{17}$ Makna kedua ini yang

${ }^{17}$ E. W. Vierdag, The Concept of Discrimination in International Law (Netherlands: Martinus Nijhott, 1973), 48. 
lebih sering dan relevan digunakan saat ini dalam konteks sosial.

\section{Dalam Kamus Besar Bahasa}

Indonesia diskriminasi diartikan dengan "pembedaan perlakuan terhadap sesama warga negara berdasarkan warna kulit, suku, golongan, agama, dan sebagainya. ${ }^{18}$ Sementara dalam pengertian ilmu sosiologi diskriminasi merupakan suatu praktik yang menggambarkan bahwa kelompok dominan atau orang-orang dengan kelas sosial atas memandang atau memperlakukan secara berbeda terhadap kelompok minoritas atau orang-orang kelas bawah dalam tatanan sosial. ${ }^{19}$

Terma "discrimination" baru pertama kali diperkenalkan serta digunakan pada awal abad ke 17 Masehi. Mulanya terma ini mendeskripsikan perlakuan tidak adil, tidak setara, dan membeda-mebedakan yang dialamatkan kepada orang lain secara personal maupun komunal atas dasar perbedaan ras. Setiap kali menyebut istilah diskriminasi maka yang dimaksud adalah diskriminasi rasial. Seiring waktu, istilah diskriminasi menjadi lebih umum dan luas cakupannya tidak hanya persoalan ras saja melainkan juga persoalan lain

18 Tim Penyusun Pusat Bahasa, Kamus Bahasa Indonesia (Jakarta: Pusat Bahasa Departemen Pendidikan Nasional, 2008), 358.

${ }^{19}$ Bryan S. Turner, ed., The Cambridge Dictionary of Sociology (New York: Cambridge University Press, 2006), 146. yang menuntut kesamaan hak seperti jenis kelamin, usia, agama, orientasi seksual dan sebagainya. ${ }^{20}$ Dengan demikian, definisi diskriminasi menurut Theodorson \& Theodorson sebagaimana dikutip oleh Fulthoni dkk. dalam buku Memahami Diskriminasi adalah perlakuan yang tidak seimbang terhadap perorangan atau kelmpok berdasarkan sesuatu-biasanya-yang bersifat kategorial atau atribut khas, seperti berdasarkan ras, kesukubangsaan, agama, atau keanggotan kelas-kelas sosial. ${ }^{21}$

Diskriminasi merupakan problem sosial yang sulit untuk dihapuskan dari tengah kehidupan masyarakat karena sudah sangat mengakar kuat bahkan membudaya dalam kehidupan sehari-hari. Sehingga kadangkala orang yang melakukan diskriminasi tidak menyadari bahwa tindakannya itu adalah sebuah tindakan yang diskriminatif. Karenanya, para pakar membagi tindakan diskriminasi kepada dua bentuk. Pertama, diskriminasi langsung, yaitu diskriminasi yang dilakukan secara langsung dan terang-terangan. Kedua, diskriminasi tidak langsung, yaitu diskriminasi yang terjadi hasil dari peraturan atau kebijakan yang semula tampak netral akan tetapi pada aplikasinya di lapangan terdapat

\footnotetext{
20 Turner, 146

21 Fulthoni et al., Memahami Diskriminasi: Buku Saku Untuk Kebebasan Beragama (Jakarta Selatan: The Indonesia Legal Resource Center, 2009), 3.
} 
perlakuan tidak adil atau membedabedakan terhadap ras tertentu, etnis, jenis kelamin, atau kategori lainnya. ${ }^{22}$

Sesuai dengan definisinya bahwa diskriminasi tidak hanya pada persoalan rasial-etnik, tetapi juga pada persoalan lainnya yang bersifat kategorial seperti agama atau kepercayaan, jenis kelamin, orientasi seksual, usia, disabilitas dan lainlain. Namun, jenis diskriminasi yang paling sering terjadi adalah diskriminasi rasial-etnik dan jenis kelamin. ${ }^{23}$ Dua jenis diskriminasi ini akan penulis diskusikan dalam artikel ini sesuai dengan hadishadis sebagaimana disebutkan di atas.

Pertama, diskriminasi rasial-etnik, yaitu tindakan diskriminasi yang berlatar belakang ras dan atau etnis. Sedangkan pengertian ras sendiri adalah mengacu pada karakteristik fisik seperti warna kulit, bentuk wajah, struktur tubuh, rambut, dan sebagainya. Etnis mengacu pada karakter non-fisik seperti bahasa, suku, warga-negara, dan sebagainya. ${ }^{24}$ Istilah ras dan etnis sering digunakan

22 Oran Doyle, "Direct Discrimination, Indirect Discrimination and Autonomy," Oxford Journal of Legal Studies 27, no. 3 (2007): 539, https://www.jstor.org/stable/4494598.

23 Lihat Ester Indahyani Jusuf, Konvensi Internasional tentang Penghapusan Segala Bentuk Diskriminasi Rasial: Sebuah Kajian Hukum tentang Penerapannya di Indonesia (Jakarta: Elsam, 2005), 1; Lihat juga Hesti Armiwulan, "Diskriminasi Rasial dan Etnis sebagai Persoalan Hukum dan Hak Asasi Manusia," MasalahMasalah Hukum 44, no. 4 (Oktober 2015): 494, https://doi.org/10.14710/mmh.44.4.2015.493-502. 490.

24 Turner, The Cambridge Dictionary of Sociology, tertukar oleh sebagian orang. Kedua, diskriminasi jenis kelamin, ini sering terjadi di ruang publik seperti dalam pekerjaan, pendidikan, atau hanya sekadar dalam pergaulan sosial. Diskriminasi ini umumnya dialami oleh perempuan yang selalu dianggap sebagai kaum lemah dan tidak setara dengan lakilaki. Di lingkungan masyarakat yang masih memegang budaya patriarki praktik diskriminasi terhadap kaum perempuan masih masif terjadi. Salah satu faktor terjadinya tindakan diskriminasi adalah doktrin keagamaan yang disalahpahami.

\section{Hadis-Hadis Bernarasi Diskriminatif}

\section{Pemimpin Harus dari Suku Quraish}

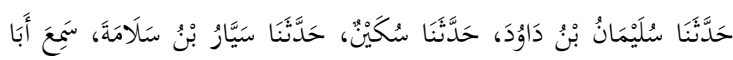

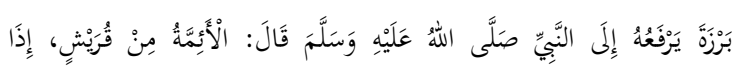

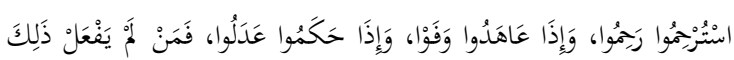

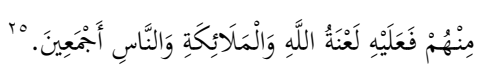

Sulaimān ibn Dāwūd menceritakan kepada kami, Sukain menceritakan kepada kami, Sayyār ibn Salāmah menceritakan kepada kami, ia mendengar Abū Barzah yang memarfu'kannya kepada Nabi saw., beliau bersabda, "pemimpin itu dari kalangan

${ }^{25}$ Ahmad Ibn Hanbal, Musnad Ahmad Ibn Hanbal, ed. oleh Syu' aib Al-Arnaūt, ' Ādil Mursyid, dan Jamāl 'Abd Al-Lațîf, vol. 33 (Beirut: al-Risālah, 1999), 21. Hadis serupa terdapat pada Abū Bakr ibn Abī Syaibah, Al-Kitāb alMușannaf fi al-Ahāàìs wa al-Āsiār, ed. oleh Kamāl Yūsuf AlḤūt, vol. 6 (Riyāḍ: Maktabah al-Rusyd, 1988), 402. Abū Dāwūd Sulaimān ibn Dāwūd Al-Ṭayālisīi, Musnad Abì Dāwūd al-Ṭayalisī, ed. oleh Muḥammad ibn 'Abd AlMuhsin, vol. 3 (Mesir: Dār Hijr, 1999), 595. 
Quraisy, apabila diminta bersikap kasih mereka mengasihi, apabila berjanji mereka menepati, apabila menghukum mereka menghukum dengan adil. Barangsiapa di antara mereka tidak melakukan hal tersebut, maka atasnya laknat Allah, malaikat, dan manusia seluruhnya."

Secara literal hadis ini menjelaskan bahwa imam-imam (pemimpin) harus (dipilih) dari kalangan suku Quraisy. Mengapa suku Quraisy? Dalam hadis dijelaskan bahwa suku Quraisy memiliki tiga karakter yang harus dimiliki oleh seorang pemimpin yakni pengasih, adil dan menepati janji. Apabila hadis ini dipahami "bulat-bulat" tanpa mengkritisi kandungan maknanya maka itu cukup problematis terutama dalam konteks kekinian. Pertama, kata al-aimmah/al-imām yang diartikan pemimpin dalam hadis ini belum jelas apakah pemimpin agama, negara, atau negara dan agama sekaligus. Kedua, keadaan umat Islam saat ini yang tidak lagi di bawah satu kekuasaan kepemimpinan, baik negara Islam maupun negara yang mayoritas penduduknya muslim masing-masing telah memiliki sistem pemerintahan berikut mekanisme pemilihan pemimpinnya. Ketiga, eksistensi suku Quraisy yang mungkin masih ada hingga hari ini namun tidak banyak. Keempat, pengkhususan suku Quraisy sebagai suku yang berhak menjadi pemimpin merupakan diskriminasi terhadap sukusuku lain. Oleh karena itu, memahami hadis di atas tidak cukup secara tekstual melainkan harus dipahami secara kontekstual yaitu dengan menganalisa bahasa serta konteks sosio-historisnya.

Kata الأئمة adalah bentuk plural dari kata الإمام yang berarti imam, pemimpin, atau kepala. ${ }^{26}$ Dalam al-Qur'an kata alimām disebutkan sebanyak tujuh kali ${ }^{27}$ dan memiliki makna yang berbeda-beda. Misalnya, dalam QS. Al-Ḥijr (15): 79 kata imām diartikan dengan tarīq (jalan); kata imām dapat pula bermakna kitāb/pedoman seperti dalam QS. Yāsīn (36): 12, QS. Hūd (11): 17, dan QS. Al-Aḥāă (46): 12; atau bermakna pemimpin seperti dalam QS. Al-Baqarah (2): 124, QS. Al-Furqān (25): 74, dan QS. Al-Isrā' (17): 71. Sementara kata al-a'immah disebutkan sebanyak empat kali28 yang keseluruhannya mengacu kepada makna pemimpin atau kepala (person).

Sebelum Islam datang, Arab belum memiliki sistem pemerintahan yang dikuasai oleh seorang pemimpin. Bangsa Arab pada masa itu hidup dalam sistem kesukuan dan berkelompok-kelompok yang dikenal dengan sebutan kabilah.

\footnotetext{
26 A.W. Munawwir, Kamus al-Munawwir ArabIndonesia (Yogyakarta: Pondok Pesantren Al-Munawwir, 1984), 40.

27 Muhammad Fu'ād 'Abd Al-Bāqīi, Al-Mu'jam al-Mufahras li Alfāz al-Qur'ān al-Karìm (Kairo: Dār al-Kutub al-Mishriyyah, 1945), 80.

${ }_{28}$ Al-Bāqīi, 81.
} 
Setiap kabilah memiliki seorang pemimpin yang mereka anggap paling senior dan memiliki kedudukan yang terhormat serta berpengaruh. ${ }^{29}$ Setiap kabilah memiliki fungsi tersendiri dalam struktur masyarakat Arab, misalnya kabilah Quraisy berfungsi sebagai pemegang atau pengurus Ka'bah. Setelah Islam hadir tepatnya pada periode Madinah barulah bangsa Arab memiliki sistem pemerintahan di bawah satu kepemimpinan. Pemimpin pertama ialah Nabi Muhammad saw. yang kemudian diteruskan oleh al-Khulafā' al-Rāsyidūn. Kepemimpinan Muhammad saw. bukan semata urusan agama tetapi beliau juga memimpin sebuah negara yang penduduknya hidup dalam kemajemukan suku dan agama. Oleh karena itu, menurut Ibn Ḥajr al-`Asqalānī bahwa yang dimaksud dengan al-a'immah dalam hadis ini ialah al-khulafä' (khalifah; pemimpin negara khilafah). ${ }^{30}$

Quraisy merupakan kabilah yang berpengaruh di dunia Arab baik sebelum maupun setelah kedatangan Islam. Kata Quraisy diambil dari kata dasar qarasyayaqrisyu-qarsyan yang berarti mengumpulkan, menggabungkan, mengusahakan sesuatu dari sana sini; atau

\footnotetext{
29 Susmihara dan Rahmat, Sejarah Islam Klasik (Yogyakarta: Ombak, 2013), 5-6.

30 Ibn Hajr Al-'Asqalānī, Fath al-Bārī Syarh Șaḥịh al-Bukhārì, ed. oleh Muhammaf Fu'ād 'Abd Al-Bāqī, vol. 13 (Beirut: Dār al-Ma'rifah, 1960), 119.
}

diambil dari kata taqarrasya al-qaum yang bermakna tajamma'a yaitu berkumpul, berkerumun, atau berkelompok. ${ }^{31}$ Pendapat lain mengatakan dinamakannya Quraisy karena berkumpulnya mereka di sekitar Mekkah setelah terpisah ke berbagai negeri; atau karena kebiasaan mereka pergi ke berbagai negeri untuk mencari rezeki dan ahli dalam perdagangan. Ada pula yang berpendapat bahwa kata Quraisy bermakna binatang yang hidup di laut dan memangsa binatang-binatang lainnya. ${ }^{32}$ Suku Quraisy memang terkenal sebagai suku yang besar, kuat dan pandai berdagang. Peran suku Quraisy sangat besar di kalangan masyarakat Arab. Bahkan, menurut pakar sejarah, Quraisy merupakan simbol kekuatan, kekuasaan, dan keperkasaan orang Arab.

Kendati demikian, para ulama seperti al-Qurțubī,33 al-'Asqalānī,34 alMawardi 35 dan lainnya menetapkan kriteria "suku Quraisy" sebagai salah satu persyaratan dalam mengangkat seorang pemimpin. Pemahaman tekstual seperti ini telah menjadi pendapat mayoritas

\footnotetext{
31 Ibn Manzūur, Lisān al-'Arab (Kairo: Dār alMa'ārif, n.d.), 3585.

32 Manzūir, 3586.

${ }^{33}$ Muhammad ibn Aḥmad Al-Qurțubī, Tafsìr alQurțubī, ed. oleh Aḥmad Al-Bardūnī dan Ibrāhīm Atṭīsy, vol. 1 (Kairo: Dār al-Kutub al-Mișriyyah, 1964), 270.

34 Al-'Asqalānī, Fatḥ al-Bārì Syarh Șahịh alBukhārī, 1960, 13:118.

35 'Alī ibn Muhammad Al-Māwardī, Al-Ahkām al-Sulțāniyah, ed. oleh Aḥmad Jād (Kairo: Dār al-Ḥadìs̀, 2006), 20.
} 
ulama selama berabad-abad. Akan tetapi, dalam konteks sekarang pemahaman seperti demikian tidak lagi relevan dan terkesan diskriminatif. Di samping juga tidak sejalan dengan semangat al-Qur'an yang ingin menghapuskan praktik rasisme sebagaimana dalam QS. Al-Ḥujurāt (49): 13. Oleh karena itu, hadis ini harus dipahami secara kontekstual. Artinya, untuk memahami hadis ini agar relevan dengan konteks kekinian dan tidak diskriminatif maka perlu mempertimbangkan substansi serta signifikansi yang terkandung dalam hadis tersebut. Karena hal itu dapat menjembatani antara konteks munculnya hadis pada masa awal Islam dan konteks di mana hadis itu kembali dipahami.

Pada masa Nabi suku Quraisy merupakan kelompok yang besar, kuat, dan berpengaruh baik secara kualitas maupun kuantitas. Secara politis, apabila kepemimpinan diserahkan kepada kelompok lain potensial terjadinya perpecahan, perselisihan, dan ketidakpatuhan kepada pemimpin. Oleh karena itu, Nabi mengisyaratkan agar pemimpin diangkat dari kalangan Quraisy, dimaksudkan untuk meminimalisir terjadinya perpecahan dan pertiakaian. Khalil Abdul Karim juga menegaskan bahwa suku Quraisy selalu cenderung menghindari peperangan antarsesama, ${ }^{36}$ terlepas motif utamanya adalah demi keamanan dan kelancaran bisnis perdagangan. ${ }^{37}$ Dengan demikian, dapat dipahami bahwa substansi dari pernyataan Nabi tersebut adalah karakter kepemimpinan sebagaimana yang dimiliki oleh kaum Quraisy pada saat itu, bukan etnisnya. Nabi kemudian menegaskan bahwa karakter seorang pemimpin antara lain adalah apabila diminta bersikap kasih mereka mengasihi, apabila berjanji mereka menepati, apabila menghukum mereka menghukum dengan adil.

\section{Kepemimpinan Perempuan}

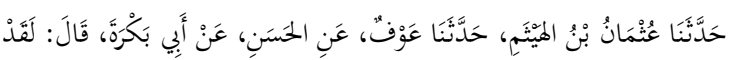

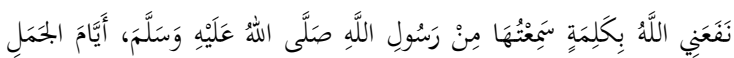

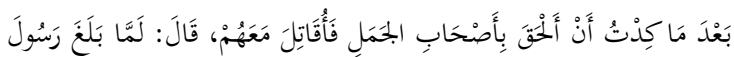

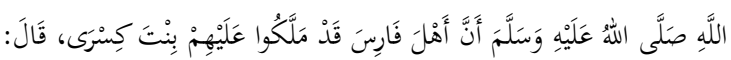

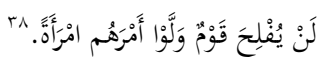

'Usimān ibn al-Hais̄ām telah menceritakan kepada kami, 'Auf telah menceritakan kepada kami, dari al-Hasan, dari Abī Bakrah, ia berkata: sungguh Allah telah memberikan

\footnotetext{
${ }^{36}$ Lihat Khalil Abdul Karim, Hegemoni Quraisy: Agama, Budaya, Kekuasaan (Yogyakarta: LKiS, 2012), 63.

37 Lihat Muhammad Quraish Shihab, Membaca Sirah Nabi Muhammad Saw dalam Sorotan al-Qur'an dan Hadits-Hadits Shahih (Jakarta: Lentera Hati, 2012), 504.

38 Abū Abdillāh Muhammad bin Ismā'îl AlBukhārī, Al-Jāmi' al-Ṣahịh, ed. oleh Muhammad Fu'ād 'Abd Al-Bāqī, vol. 3 (Kairo: al-Salafiyah, 1978), 181. Hadis ini juga diriwayatkan Muhammad Ibn 'Isā Al-Tirmiżī, Sunan al-Tirmiżī, ed. oleh Ibrāhīm 'Ațwah, vol. 4 (Kairo: Mușțafā al-Bābī al-Ḥalabī, 1937), 527-28 .Aḥmad Ibn Syu'aib AlNasā'î, Sunan al-Nasā'î, ed. oleh 'Abd al-Fattāh Abū Ghuddah, vol. 8 (Halab: Islāmiyyah, 1986), 227.Ahmad ibn Hanbal, Musnad Ahmad Ibn Hanbal, ed. oleh Syu'aib AlArnaūṭ, 'Ādil Mursyid, dan Hais̄ām 'Abd Al-Ghafūr, vol. 34 (Beirut: al-Risālah, 1999), 43 .
} 
manfaat kepadaku dengan satu kalimat yang pernah aku dengar dari Rasulullah saw., pada hari perang Jamal tatkala aku hampir bergabung dengan penunggang unta dan berperang bersama mereka. Ia berkata lagi: tatkala Rasulullah saw. diberitahu bahwa penduduk Persia dipimpin oleh seorang putri raja Kisra, Nabi pun bersabda: "tidak akan sukses/menang suatu kaum yang menyerahkan urusan mereka kepada seorang perempuan."

Potongan hadis yang berbunyi "tidak akan menang/sukses suatu kaum yang menyerahkan urusan mereka kepada seorang perempuan" selalu menjadi legitimasi bagi sebagian kelompok orang yang memandang bahwa perempuan tidak boleh atau tidak becus menjadi seorang pemimpin atau jabatan strategis lainnya. Al-Qāọī Abū Bakar ibn al-'Arabī mengatakan bahwa hadis ini adalah dalil tidak diperkenankannya perempuan menjadi seorang khalifah (pemimpin). ${ }^{39}$ Ibn Hajr berpendapat bahwa perempuan menurut syari'at hanya diberi tanggung jawab pada persoalan domestik saja seperti mengurus suami, anak, dan rumah tangga. Pendapat yang lebih bias gender datang dari Muḥammad ibn Șāliḥ al'Uśaimīn yang mengatakan perempuan adalah makhluk yang lemah. Menurutnya, hadis di atas bersifat universal dan berlaku sampai kapan pun. Meskipun,

${ }^{39}$ Muhammad ibn 'Abdullah Abū Bakr ibn Al'Arabī, Ahkām al-Qur'ān, ed. oleh Muhammad 'Abd alQādir 'Ațā, vol. 3 (Beirut: Dār al-Kutub al-'Ilmiyah, 2003), 482. terdapat sementara perempuan yang berhasil menjadi seorang pemimpin, namun hal tersebut tidak terlepas dari peran laki-laki yang membantunya. 40 Menurut Quraish Shihab, ia menduga bahwa pemahaman ulama terdahulu dipengaruhi kondisi masyarakat dan kaum perempuan pada masa mereka. Masih menurutnya, ulama terdahulu kurang memperhatikan betapa banyak tokok perempuan yang sukses menjadi seorang pemimpin negeri dan peranperan lainnya. ${ }^{41}$

Penting kiranya memahami hadis ini dengan melihat konteks sosio-historis baik makro maupun mikro. Berdasarkan redaksi lengkapnya, hadis ini dimunculkan kembali oleh Abū Bakrah pada saat terjadinya perang Jamal, yaitu konflik antara 'Alī ibn Abī Ṭālib dan 'Ā'isyah janda Rasulullah saw. Abū Bakrah yang semula berpihak kepada 'ÁA'isyah tiba-tiba berpaling kepada 'Alī ibn Abī Ṭālib karena ia teringat ucapan Rasulullah saw. yang pernah ia dengar yakni komentar Nabi ketika mendengar informasi bahwa kerajaan Persia dipimpin oleh seorang putri raja Kisra yang bernama Buwaran binti Syirawaih (Kisra)

40 Muhammad ibn Șālị̣ Al-'Usaimīn, Tafsīr alQur'ān al-Karim, vol. 1 (Saudi Arabia: Muassasah al-Syeikh Muḥammad ibn Șāliḥ al-'Uṡaimīn, 2015), 87-88.

41 Muhammad Quraish Shihab, Islam yang Disalah-Pahami (Tanggerang: Lentera Hati, 2018), 169. 
bin Abrawaiz bin Hurmuz. ${ }^{42}$ Berdasarkan keterangan ini, menurut Quraish Shihab penting untuk menggarisbawahi bahwa hadis ini bersifat khusus, tidak bersifat umum. ${ }^{43}$ Senada dengan itu, Syuhudi Ismail memandang hadis ini bersifat temporal ${ }^{44}$ atau bersifat kasuistik.

Tradisi kepemimpinan yang berlaku di Persia pada masa itu adalah bersifat patriarki. Sebelum Buwaran kerajaan Persia tidak pernah dipimpin oleh seorang perempuan. Ketika ayahnya, Syirawaih (Kisra), meninggal dunia seharusnya yang menjadi penerus tonggak kepemimpinan adalah anak lakilakinya. Namun, saudara laki-laki Buwaran ternyata telah mati terlebih dahulu yaitu terbunuh saat tragedi perebutan kekuasaan. ${ }^{45}$ Satu-satunya orang yang bakal menjadi pemimpin adalah Buwaran. Sedangkan stereotip yang terbangun di masyarakat Persia termasuk juga Arab dan lainnya pada waktu itu adalah perempuan merupakan makhluk yang rendah derajatnya di bawah laki-laki, sehingga tidak diberikan

\footnotetext{
42 Al-'Asqalānī, Fath al-Bārī Syarh Sạhịh alBukhārī, 1960, 13:56.

43 Muhammad Quraish Shihab, Wawasan alQur'an: Tafsir Maudhu'i atas Pelbagai Persoalan Umat (Bandung: Mizan, 1996), 314.

${ }_{44}$ Muhammad Syuhudi Ismail, Hadis Nabi yang Tekstual dan Kontekstual: Telaah Ma'ani al-Hadits tentang Ajaran Islam yang Universal, Temporal, dan Lokal (Jakarta: Bulan Bintang, 2009), 67.

45 Ibn Hajr Al-'Asqalānī, Fath al-Bārī Syarh Șahīh al-Bukhārī, ed. oleh Muhammaf Fu'ād 'Abd Al-Bāqī, vol. 8 (Beirut: Dār al-Ma'rifah, 1960), 128.
}

kepercayaan untuk mengurus kepentingan umum termasuk memimpin sebuah kerajaan. ${ }^{46}$ Oleh karena itu, tidak keliru jika Nabi saw. berkomentar demikian, mengingat masyarakat yang akan dipimpin oleh Buwaran nantinya adalah masyarakat yang tidak bisa menghargai perempuan apalagi mematuhinya.

Dan hal yang menarik adalah selang beberapa waktu setelah komentar Nabi tersebut kerajaan Persia mengalami kekacauan, perselisihan, bahkan pembunuhan yang dilakukan oleh keluarga dekat kerajaan. Ini semakin menguatkan argumen bahwa hadis ini tidak berlaku secara universal. Sejarah juga mencatat betapa banyak perempuan yang berhasil menjadi seorang pemimpin atau peran strategis lainnya, salah satunya, termaktub dalam al-Qur'an kisah keberhasilan kepemimpinan Ratu Balqis. ${ }^{47}$

\section{Kesimpulan}

Dalam konsep kepemimpinan terutama mengenai persoalan memilih pemimpin baik Islam maupun HAM tidak saling bertentangan. Islam tidak membatasi siapa yang berhak menjadi pemimpin dengan alasan-alasan yang

46 Ismail, Hadis Nabi yang Tekstual dan Kontekstual: Telaah Ma'ani al-Hadits tentang Ajaran Islam yang Universal, Temporal, dan Lokal, 65.

47 Lihat Syamsuddin, Hermeneutika dan Pengembangan Ulumul Qur'an, 160. 
diskriminatif. Sama halnya dengan prinsip HAM yang tidak menghalangi siapa saja yang ingin menjadi pemimpin atau jabatan-jabatan strategis lainnya. Narasinarasi agama yang mengandung unsur diskriminatif seperti hadis yang hanya mengharuskan pemimpin berasal dari kalangan suku tertentu; atau hadis yang melarang perempuan menjadi seorang pemimpin sebenarnya lahir dari pemahaman tekstual yang oleh sebagian orang meyakininya sebagai ajaran normatif. Oleh karena itu, untuk memahami hadis-hadis seperti demikian seharusnya menggunakan pendekatan kontekstual karena suatu teks tidak lahir dari kehampaan ruang sosial yang mengitarinya. Dengan demikian, hadis yang mengharuskan pemimpin diangkat dari kalangan Quraisy apabila dipahami secara kontekstual maka pesan yang terkandung adalah instruksi Nabi kepada masyarakatnya waktu itu agar memilih pemimpin yang memiliki kewibawaan, kecakapan, dan pengalaman sebagaimana kaum Quraisy. Sedangkan hadis yang mencemooh kepemimpinan perempuan tidak tepat jika menjadikannya sebagai landasan untuk melarang kaum perempuan menjadi pemimpin, hakim, atau jabatan strategis lainnya. Pesan yang terkandung dalam hadis ini adalah bahwa kesuksesan seorang pemimpin tergantung pada pandangan dan pengaruhnya di mata masyarakat. Bagaimana mungkin seorang yang tidak dihargai oleh masyarakatnya sendiri bisa sukses dalam memimpin sebuah negara sebagaimana potret kepemimpinan Ratu Buwaran binti Syirawaih (Kisra) yang mengalami kegagalan.

\section{Referensi}

1. Abdillah, Masykuri. Demokrasi di Persimpangan Makna. Yogyakarta: Tiara Wacana, 1999.

2. Al-'Arabī, Muhammad ibn 'Abdullah Abū Bakr ibn. Ahkām alQur'ān. Diedit oleh Muhammad 'Abd al-Qādir 'Ațā. Vol. 3. Beirut: Dār al-Kutub al-'Ilmiyah, 2003.

3. Al-'Asqalānī, Ibn Hajr. Fath al-Bārī Syarh Șahịh al-Bukhārì. Diedit oleh Muhammaf Fu'ād 'Abd Al-Bāqī. Vol. 13. Beirut: Dār al-Ma'rifah, 1960.

4. - - - Fath al-Bārī Syarh Sahịh alBukhārì. Diedit oleh Muhammaf Fu'ād 'Abd Al-Bāqī. Vol. 8. Beirut: Dār al-Ma'rifah, 1960.

5. Al-`Uṡaimīn, Muhammad ibn Ṣāliḥ. Tafsìr al-Qur'ān al-Karìm. Vol. 1. Saudi Arabia: Muassasah al-Syeikh Muhammad ibn Ṣāliḥ al-'Uśaimīn, 2015.

6. Al-Bāqī, Muhammad Fu'ād 'Abd. Al-Mu'jam al-Mufahras li Alfäz alQur'ān al-Karim. Kairo: Dār alKutub al-Mishriyyah, 1945.

7. Al-Bukhārī, Abū Abdillāh Muḥammad bin Ismā'îl. Al-Jāmi' alSahịh. Diedit oleh Muhammad Fu'ād 'Abd Al-Bāqī. Vol. 3. Kairo: al-Salafiyah, 1978.

8. Al-Māwardī, 'Alī ibn Muhammad. Al-Ahkām al-Sulțāniyah. Diedit oleh Aḥmad Jād. Kairo: Dār al-Ḥadìs, 
2006.

9. Al-Nasā'ì, Aḥmad Ibn Syu'aib. Sunan al-Nasā' al-Fattāh Abū Ghuddah. Vol. 8. Halab: Islāmiyyah, 1986.

10. Al-Qurțubī, Muhammad ibn Ahmmad. Tafsìr al-Qurțbì. Diedit oleh Aḥmad Al-Bardūn̄i dan Ibrāhīm Aṭ̂īsy. Vol. 1. Kairo: Dār al-Kutub al-Mișriyyah, 1964.

11. Al-Ṭayālisī, Abū Dāwūd Sulaimān ibn Dāwūd. Musnad Abī Dāwūd alTayālisī. Diedit oleh Muhammad ibn 'Abd Al-Muhsin. Vol. 3. Mesir: Dār Hijr, 1999.

12. Al-Tirmiżī, Muhammad Ibn 'Isā. Sunan al-Tirmiżi. Diedit oleh Ibrāhīm 'Ațwah. Vol. 4. Kairo: Mușțafā al-Bābī al-Halabī, 1937.

13. Armiwulan, Hesti. "Diskriminasi Rasial dan Etnis sebagai Persoalan Hukum dan Hak Asasi Manusia." Masalah-Masalah Hukum 44, no. 4 (Oktober 2015): 493-502-502. https://doi.org/10.14710/mmh.44 .4.2015.493-502.

14. Auda, Jasser. Membumikan Hukum Islam Melalui Maqasid Syariah. Diterjemahkan oleh Rosidin dan 'Ali 'Abd el-Mun'im. Bandung: Mizan Pustaka, 2015.

15. Baehr, Peter, Pieter van Dijk, Adnan Buyung Nasution, dan Leo Zwaak. Instrumen Internasional Pokok Hak Asasi Manusia. Disunting \& diterjemahkan oleh Adnan Buyung Nasution dan A. Patra M. Zen. Jakarta: Yayasan Obor Indonesia, 2006.

16. Bahasa, Tim Penyusun Pusat. Kamus Bahasa Indonesia. Jakarta: Pusat Bahasa Departemen Pendidikan Nasional, 2008.

17. Doyle, Oran. "Direct Discrimination, Indirect Discrimination and Autonomy." Oxford Journal of Legal Studies 27, no. 3 (2007): 537-53. https://www.jstor.org/stable/449
4598.

18. Fulthoni, Renata Arianingtyas, Siti Aminah, dan Uli Parulian Sihombing. Memahami Diskriminasi: Buku Saku Untuk Kebebasan Beragama. Jakarta Selatan: The Indonesia Legal Resource Center, 2009.

19. Hanbal, Ahmad ibn. Musnad Ahmad Ibn Hanbal. Diedit oleh Syu'aib Al-Arnaūt, 'Ādil Mursyid, dan Hais̄ām 'Abd Al-Ghafūr. Vol. 34. Beirut: al-Risālah, 1999.

20. Hanbal, Aḥmad Ibn. Musnad Ahmad Ibn Hanbal. Diedit oleh Syu'aib Al-Arnaūt, 'Ādil Mursyid, dan Jamāl 'Abd Al-Lațif. Vol. 33. Beirut: al-Risālah, 1999.

21. Ismail, Muhammad Syuhudi. Hadis Nabi yang Tekstual dan Kontekstual: Telaah Ma'ani al-Hadits tentang Ajaran Islam yang Universal, Temporal, dan Lokal. Jakarta: Bulan Bintang, 2009.

22. Jusuf, Ester Indahyani. Konvensi Internasional tentang Penghapusan Segala Bentuk Diskriminasi Rasial: Sebuah Kajian Hukum tentang Penerapannya di Indonesia. Jakarta: Elsam, 2005.

23. Karim, Khalil Abdul. Hegemoni Quraisy: Agama, Budaya, Kekuasaan. Yogyakarta: LKiS, 2012.

24. Khallaf, Abdul Wahhab. Ilmu Ushul Fiqih. Diterjemahkan oleh Moh Zuhri dan Ahmad Qarib. Semarang: Dina Utama, 2014.

25. Madjid, Nurcholish. "Konsep Islam tentang Manusia dan Implikasinya terhadap Apresiasi Muslim Mengenai Hak-Hak Sipil dan Politik." In Islam dan Humanisme: Aktualisasi Humanisme Isam di Tengah Krisis Humanisme Universal. Yogyakarta: Pustaka Pelajar, 2007.

26. Manzuūr, Ibn. Lisān al-'Arab. Kairo: Dār al-Ma'ārif, n.d.

27. Maufur, Norhaidi Hasan, dan 
Syaifudin Zuhri. Modul Pelatihan Figh dan HAM. Yogyakarta: LKiS, 2014.

28. Maulana, Makhrur Adam. Konsepsi HAM dalam Islam antara Universalitas dan Partikularitas. Yogyakarta: Pustaka Ilmu, 2015.

29. Munawwir, A.W. Kamus alMunawwir Arab-Indonesia. Yogyakarta: Pondok Pesantren AlMunawwir, 1984.

30. Shihab, Muhammad Quraish. Islam yang Disalah-Pahami. Tanggerang: Lentera Hati, 2018.

31. - - - Membaca Sirah Nabi Muhammad Saw dalam Sorotan alQur'an dan Hadits-Hadits Shahih. Jakarta: Lentera Hati, 2012.

32. - - - Membumikan al-Qur'an: Fungsi dan Peran Wahyu dalam Kehidupan Masyarakat. Bandung: Mizan, 2013.

33. - - - Wawasan al-Qur'an: Tafsir Maudhu'i atas Pelbagai Persoalan Umat. Bandung: Mizan, 1996.

34. Susmihara, dan Rahmat. Sejarah Islam Klasik. Yogyakarta: Ombak, 2013.

35. Syaibah, Abū Bakr ibn Abī. AlKitāb al-Muṣannaf fi al-Ahādì̀s wa al$\bar{A} \dot{s} \bar{a} r$. Diedit oleh Kamāl Yūsuf AlHūt. Vol. 6. Riyāḍ: Maktabah alRusyd, 1988.

36. Syamsuddin, Sahiron. Hermeneutika dan Pengembangan Ulumul Qur'an. Yogyakarta: Pesantren Nawesea, 2017.

37. Turner, Bryan S., ed. The Cambridge Dictionary of Sociology. New York: Cambridge University Press, 2006.

38. Vierdag, E. W. The Concept of Discrimination in International Law. Netherlands: Martinus Nijhott, 1973.

39. Wahid, Abdurrahman. "Universalisme Islam dan Kosmopolitanisme Peradaban Islam." In Islam Universal. Yogyakarta: Pustaka Pelajar, 2007. 